\title{
DETERMINATION OF THE WIND-ERODIBLE FRACTION OF SOILS USING DIFFERENT METHODOLOGIES
}

\author{
M.V. López¹, J.M. de Dios Herrero², G.G. Hevia², R. Gracia'1, D.E. Buschiazzo ${ }^{2,3}$ \\ ${ }^{1}$ Estación Experimental de Aula Dei (CSIC), Apdo. 202, 50080 Zaragoza, Spain. \\ 2 Universidad Nacional de la Pampa, 6300 Santa Rosa, La Pampa, Argentina. ${ }^{3}$ INTA and CONICET, Argentina.
}

\section{INTRODUCTION}

- The wind-erodible fraction of soils $(E F)$ is a key parameter to estimate the soil susceptibility to wind erosion.

- The standard method for EF determination is the dry sieving by means of a rotary sieve (Photo 1 ). However, the rotary sieve is not commercially available and other alternative methods have been developed to obtain EF.

- The flat sieve with a set of sieves -a device more readily available in the laboratories of soil physics- (Photo 2) and the use of the estimation equation developed by Fryrear et al. (1994) (J. Soil and Water Cons., 49: 183-188) are two alternative ways of determining $E F$.

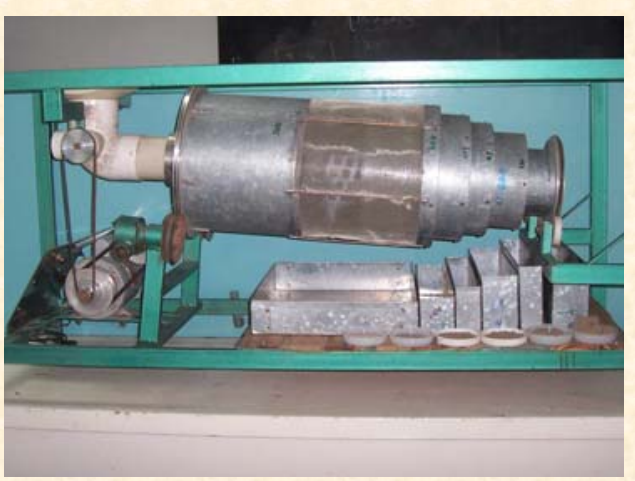

Photo 1. Standard rotary sieve.

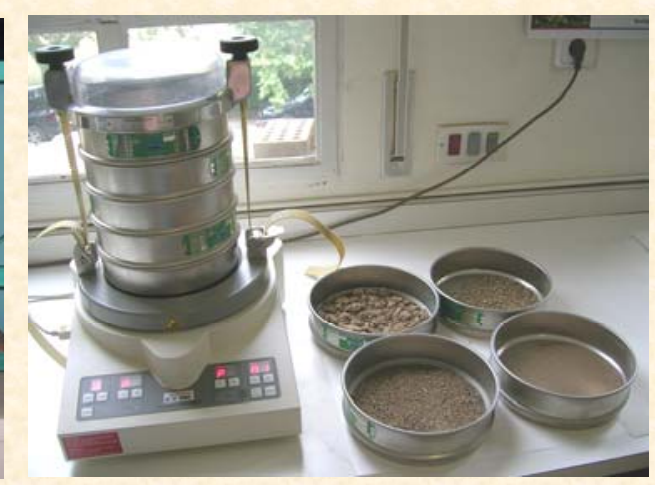

Photo 2. Flat sieve.
- We compare here both dry sieving techniques and test the equation of Fryrear et al. (1994) for soils of two semiarid regions prone to wind erosion, Central Aragon (NE Spain) and the Semiarid Pampas (centre of Argentina).

\section{MATERIALS AND METHODS}

- A total de 81 fields were selected from Central Aragon (agricultural soils) and the Semiarid Pampas (soils of "calden" forest, Prosopis caldemia, and adjacent agricultural soils).

- Three soil samples per field were collected from the upper $2.5 \mathrm{~cm}$ to determine, by the standard methods, particle size distribution, organic matter content and $\mathrm{CaCO}_{3}$ content.

- The EF was calculated as the percentage of dry aggregates $<0.84 \mathrm{~mm}$ in diameter separated from the soil sample by two dry sieving methods: standard sieving with the rotary sieve (Chepil, 1962. Soil Sci. Am. Proc., 26: 4-6) and flat sieving with an electromagnetic sieve shaker (FRITSCH Analysette 3 PRO).

- EF was also calculated with the equation proposed by Fryrear et al. (1994):

$E F(\%)=29.09+0.31 \%$ sand $+0.17 \%$ silt +0.33 sand/clay
$-2.59 \%$ organic matter $-0.95 \% \mathrm{CaCO}_{3}$

\section{RESULTS AND DISCUSSION}

- Figure 1 shows the strong relationship found between EF values obtained with both sieving methods, indicating that flat sieving is a suitable alternative to the standard method for EF determinations.

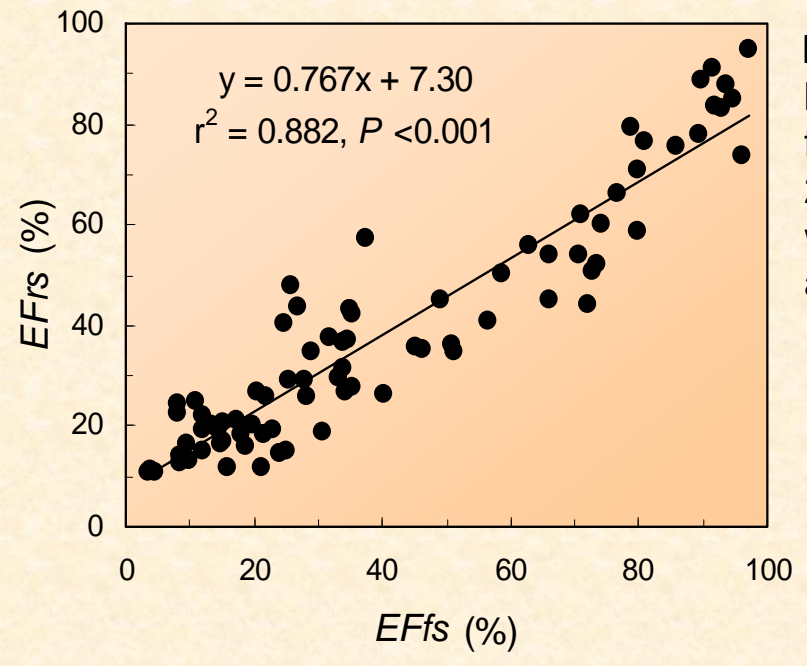

Figure 1. Relationship between the wind-erodible fraction of soil surface $(0-$ $2.5 \mathrm{~cm}$ depth) determined with the rotary sieve (EFrs) and the flat sieve (EFfs).

- The equation established by Fryrear et al. (1994) (Eq. [1]) was not successful in predicting EF neither for Spanish nor for Argentinian soils (Fig. 2). This was attributed to the high $\mathrm{CaCO}_{3}$ contents of the Spanish soils and the low sand/clay ratios and high organic matter contents of some Argentinian soils.

Figure 2. Relationship between measured (rotary sieve) and predicted winderodible fraction $(E F)$ of soil surface $(0-2.5 \mathrm{~cm}$ depth) using Eq. [1] for Argentinian and Spanish soils.

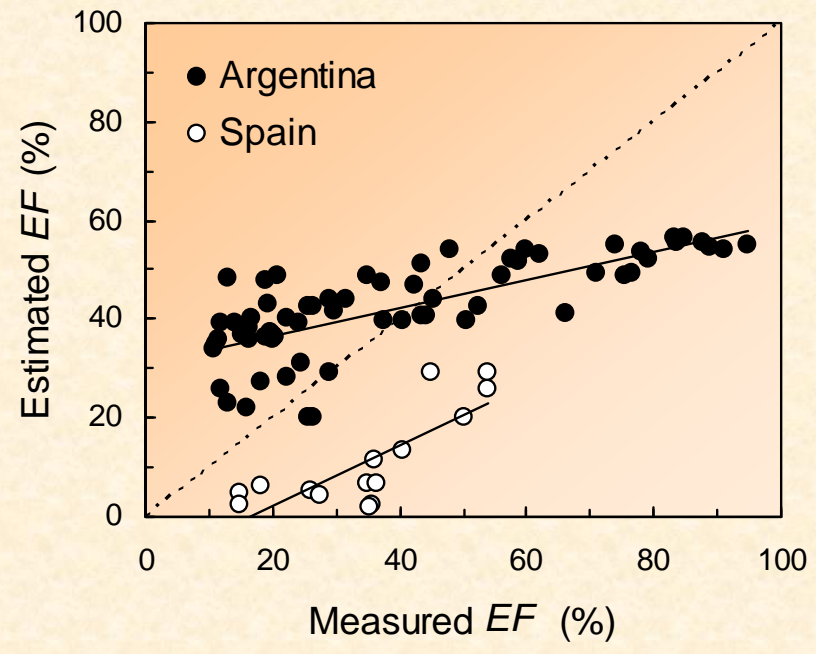

- The equations that better predicted EF for Argentinian and Spanish soils were:

$$
\begin{gathered}
\text { EFrs }(\%)=9.98+6.91 \text { sand/clay }+14.1 / \% \text { organic matter } \\
r=0.933, P<0.001 \\
\text { EFfs }(\%)=4.77+7.43 \text { sand/clay }+27.6 / \% \text { organic matter } \\
r=0.881, P<0.001
\end{gathered}
$$

\section{CONCLUSIONS}

- The flat sieving technique can be considered as a suitable alternative to the standard method for EF determinations.

- The estimation equation of EF proposed by Fryrear et al. (1994) was not useful for predicting EF for Argentinian and Spanish soils.

- The ratio sand/clay and organic matter were the best predictive variables of $E F$ in the studied soils ( $r=0.933 ; P<0.001)$ 